\title{
Design Of Inventory Data Information Systems In PT. Matahari Putra Prima. Tbk
}

\author{
Saryani ${ }^{1}$, Harfizar $^{2}$, Julio Fahmi Maulana ${ }^{3}$ \\ ${ }_{1,2,3}$ Raharja University, JL. Jendral Súdirman No.40 Modern Cikokol Tangerang \\ e-mail: saryani@raharja.info, harfizar@raharja.info, julio@raharia.info
}

\begin{abstract}
The development of technology that is developing at this time attracts a lot of public attention. Information technology as not important to run a business, therefore a computerized system is one of the supporting business success. Because with a computerized system can facilitate its use in carrying out activities or activities. The development of computers that continues to be dynamic and requires information that is fast, precise and systematic and does not require a long time. Computers have become the main tool in every human activity. Not only for business applications, but also in the daily activities of each company. This shows how computers have become part of human renewal of technology. Especially the inventory system of important items for the sales process at PT. Matahari Putra Prima Tbk in terms of inventory fields. Where still using the bookkeeping system. Data processing is still manually using Microsoft Excel and often occurs less accurate in inputting, with errors that occur when recording data items in and out so that data inventory items are ineffective and inefficient. With less than maximum, an inventory of goods data will be moved from the information needed by the customer or leader. And this research uses system design implemented with Unified Modeling Language (UML). This is the rationale for how the author analyzes the data inventory system of goods that exist in PT. Matahari Putra Prima Tbk can make it easy to input inventory data to get efficient and accurate reports.
\end{abstract}

Keywords: System, Inventory, Goods, Unified Modeling Language (UML).

\section{Introduction}

In this globalization era, information technology is very important, nowadays the development of the increasingly rapid business world requires precise, fast, and accurate information. In a situation where things are so difficult to do but with the existence of information technology all work becomes easier. To realize the right information for the company, a reliable information system is needed to support the company's operations. Therefore, almost all agencies, both government and private, use computers as a tool in data processing and work. But in order to maintain the existence and achievement of the goals of a company, it is required to build a good system.

PT. Matahari Putra Prima. Tbk as one of the companies engaged in the supply of goods with various kinds of well-known products that are stored and at the same time as the largest retail in Indonesia and has more than 160 branches in Indonesia. The produce produced can be said to be the best product, so many people shop at the center. The products are diverse, ranging from clothes, pants, shoes, bags, cosmetic tools, men's accessories, and much more.

Therefore PT. Matahari Putra Prima Tbk is a company engaged in the supply of goods, of course, has an inventory system in managing inventory [15].

But at PT. Matahari Putra Prima in documentation is still done manually and in storing data using Microsoft Excel, thus creating obstacles in the company's performance. Because of that, an information system is needed in increasing work within the company. To help, simplify, and speed 
up the inventory process of goods. Then a data inventory system of goods is needed that can fulfill needs such as data, report making, and recording.

\section{Research Method}

In carrying out the design on a system there are several important things that must be considered, including the existence of research methods to solve various formulation of the problems that exist in this research stage. In writing this journal using the 4 stages used in the research method are as follows:

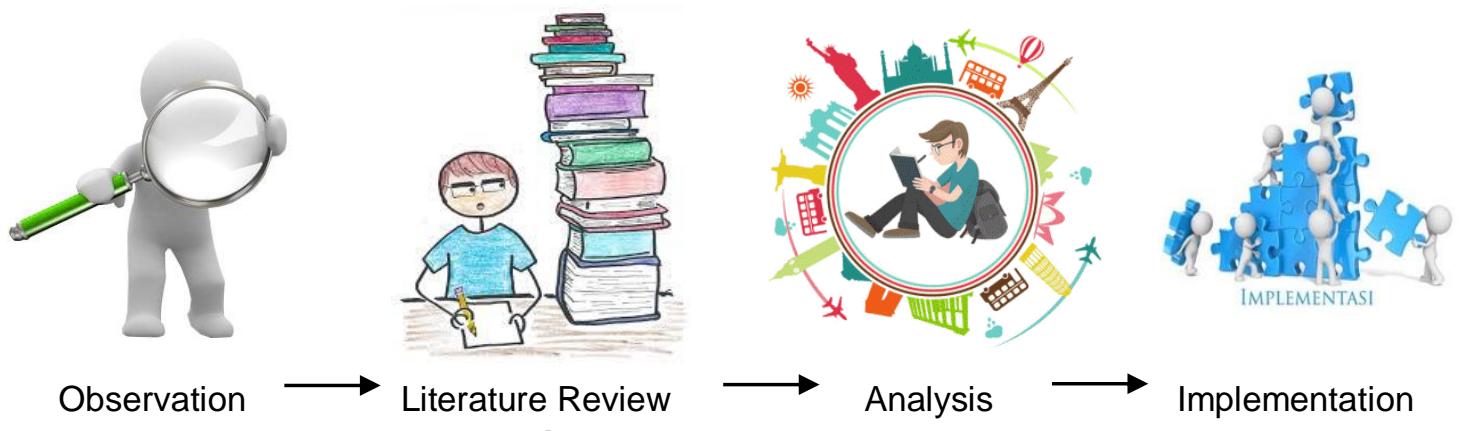

Figure 1. Research Method

\section{A. Observation}

According to Rahardja, $U$ et al in the Technomedia Journal (2018). "Observation method is a data collection technique, where researchers make observations directly on the object of research to see closely the activities and problems that are occurring that are being carried out and as a problem solving. Observation methods can also be interpreted as observing and recording systematically the symptoms seen in the research subjects [1].

\section{B. Literature Review}

According to Nur Azizah et al in the Journal of SENSI Vol. 3 No. 2 of 2017 with the title "Designing a SPG Employee Performance Assessment Information System with a Contract Status in Softe Indonesia using the Simple Additive Weighting (SAW) Method". Literature is literature or literature while review is the activity of the author in reviewing and re-examining things that have been done before, so the literature review can be concluded as an action to review and re-examine a literature or literature. Literature review contains the author's responses, summaries, and thoughts which are quoted from library sources (can be articles, books, slides, information from the internet, etc.) on topics discussed, and placed in the initial chapter [2].

In the Literature Review method the author studies, collects, and summarizes from several sources (literature) such as journals, theses, books and several reference books related to research to obtain the data and information needed and as reference material by the author in the completion of journal writing. The following is the research that has been carried out and has a correlation that is in line with the research that will be discussed in this journal, including:

1) Research conducted by Aris, A., Firdaus, T., \& Nurseha, N. (2018). APPLICATION OF GOODS QUALITY CONTROL PROGRAMS TO SUPPORT REPORTING IN THE RAHARJA HIGHER EDUCATION TECHNIQUES PART. STORY Journal, 4 (2), 159-168. In this study carried out in the Engineering section, at the Raharja College where in the engineering data processing section still not able to provide the best service to meet the strategic information needs needed to support reporting on the management of Raharja College. It takes a long time to produce goods data information as needed, this happens because it has not been integrated with 
management and information processing yet can be effective and efficient, with the design method using UML, and the making of application programs using a PHPbased website programming language. So that it can assist in reporting item data online by the engineering section for management that can improve the performance of the engineering section for Management of Raharja Higher Education so that it provides good and faster service [7].

2) Research conducted by Maulani, G., Septiani, D., \& Sahara, P. N. (2018). [2] DESIGN OF INVENTORY INFORMATION SYSTEM FOR MAINTENANCE FACILITIES IN. PLN (PERSERO) TANGERANG. ICIT Journal, 4 (2), 156 - 167. In this study the existing equipment in the warehouse of PT PLN (PERSERO) is often uncontrolled in number and usage because at that time there was no system that regulates the entry and exit of goods, so that in searching or borrowing equipment takes time which is old. The purpose of this study is to help solve the problems that occur so that the process of work activities can run well. For this reason, it is necessary to design a computerized information system that can minimize the length of the search process and maintain data security. The methodology used in this study, namely data collection methods, analysis methods, design methods and testing methods with Black Box Testing. The results of this study are in the form of an inventory information system application web-based maintenance facilities designed to build using PHP and MySQL-based programs that are suitable for accommodating all inventory information specifically for PT. PLN (Persero) maintenance facilities in Tangerang [8].

3) Researchers conducted by Ahmad Budiman, Asri Mulyani (2016). DESIGN AND DEVELOPMENT OF THE APPLICATION OF INFORMATION SYSTEMS FOR GOODS IN TB. INDAH JAYA BASED ON DESKTOP Journal of Garut Technology Algorithm Vol. 13, No. 1. In this study, discussing the design of information systems applications for desktop-based goods, the cashier section can manage and search data items quickly and can provide accurate information to the head shop owner. To overcome errors in calculating the number of items. To find out the reports of inventory in the warehouse that exist effectively. To find out the profit in the sale of goods. The method used in the design of information systems application for desktop-based goods is object-oriented methodology with the Unified Approach approach and uses modeling from the Unified Approach. the design of information system applications for desktop-based goods produced during the research process can provide solutions to existing problems by referring to the design process from the beginning, so that with this application can help in the process of finding goods and reporting data and can increase effectiveness management of goods data information at TB. Indah Jaya [9].

4) Research conducted by Erna Astriyani, Rahmadi Ahmad and Ricky Alfariz in the STORY (2017) Journal [58] entitled The Design of Goods Stock Procurement System at Pt. Laju Karunia Jaya, about the procurement of goods plays a very important role in supporting the implementation of project work, There are shortcomings and constraints on the running system, namely the application is still using semi-computerized and manual where incoming goods are inputted from purchase notes into Microsoft excel and items that will come out from the warehouse still applying manual recording with memos on paper, this causes weak control of the stock of goods in the warehouse which has an impact on lack of stock and excess stock of goods and frequent non-conformity reporting of goods, which makes it difficult in the process of returning goods to the warehouse [11].

5) Research conducted by Dedeh Supriyanti, Yudo Bangun Romadhon and Dedy Iskandar in the STORY Journal (2015) entitled The Inventory Information System at Pt.Hankook Ceramic Indonesia, explaining the problems encountered in the 
inventory information system at PT. Hankook Ceramic Indonesia is a lack of an accurate, fast and precise information system even though the inventory system at PT. Hankook Ceramic Indonesia is still using Microsoft Office, the research conducted by the author is to analyze the information system running at PT. Hankook Ceramic Indonesia. The methodology used is the system development life cycle approach starting from analyzing the system that runs through UML (Unified Modeling Language) [10].

The results of the literature review demonstrate a solid foundation and strong reasons for developing a system of information on inventory data of goods to be more effective and efficient.

\section{Analysis}

According to Sunarya et al. (2015: 4) When the planning has been completed, the next stage will shift to the analysis of the existing system. System analysis is research on existing systems with the aim of planning a new or updated system. At this stage the activities carried out are announcing system research, organizing the project team, defining information needs, defining system work criteria, preparing design proposals, approving or rejecting project designs [13-14].

In this information system analysis method, the author uses the SWOT method, namely to evaluate strengths (strengths), weaknesses (weaknesses), opportunities (opportunities), and threats (threats) into a strategy in optimizing a more profitable business.

1. According to According to Ciarmiello, A. in international journals "SWOT Analysis and Stakeholder Engagement for Comparative Evaluation of Hybrid Molecular Imaging Modalities" (2016: 271-282), SWOT Analysis is a decision support tool designed to combine internal (strengths and weaknesses) and external (opportunities and threats) factors in planning organizational or technological change [4].

2. According to Edy Susena et al in the journal Sainstech Polytechnic Indonusa Surakarta (2015: 6), "SWOT stands for Strengths, Weaknesses, Opportunities, Threats (challenges). SWOT analysis is a tool used to identify internal and external issues that affect the ability to market. SWOT analysis is a form of analysis of situations and conditions that are descriptive (giving an idea) [5].

3. According to Ezra Randalinggi (2015), SWOT Analysis is an analysis that helps in decision making in order to develop a strategy in an organization based on information and data that has been collected [3].

So a SWOT analysis is a strategic planning method used to evaluate the strengths, weaknesses, opportunities, and threats in a project or business speculation.

\section{Implementation}

According to Fauzan Masykur (2014: 184) in his journal "Implementation That is implementing a design or design by writing program code according to the chosen programming language" [6].

In this research system planning will be carried out to be applied to the process of archiving incoming letters and outgoing letters to the Office of Tourism and Culture using the PHP programming language and the Unified Modeling Language (UML) [12].

\section{Results and Analysis}

\subsection{Current System Analysis}




\section{A. Inventory System Request Order}

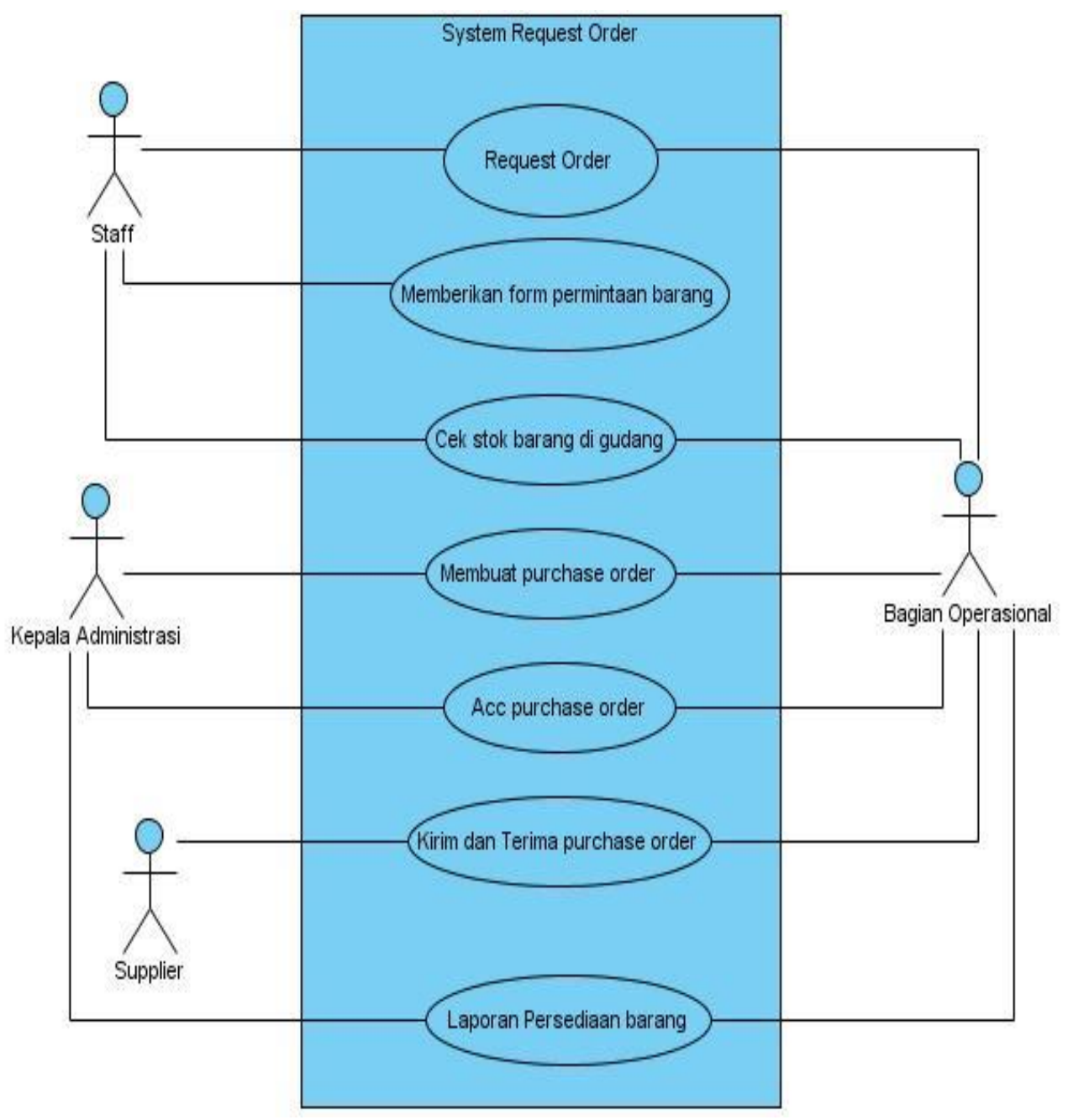

Figure 2. Request Request System diagram

Based on the image 2. Use Case Diagram that runs at this time, there are:

a. 1 (one) system that covers all activities of the Inventory Data System at PT. Matahari Putra Prima Tbk.

b. 4 (four) actors who carry out activities, namely: Staff, head of administration, operations, suppliers.

c. 7 (seven) use case diagrams commonly carried out by these actors include: order requests, making purchase orders, sending and receiving purchase orders and inventory reports.

\subsection{Proposed Program Design}

A. Display of Login Page 


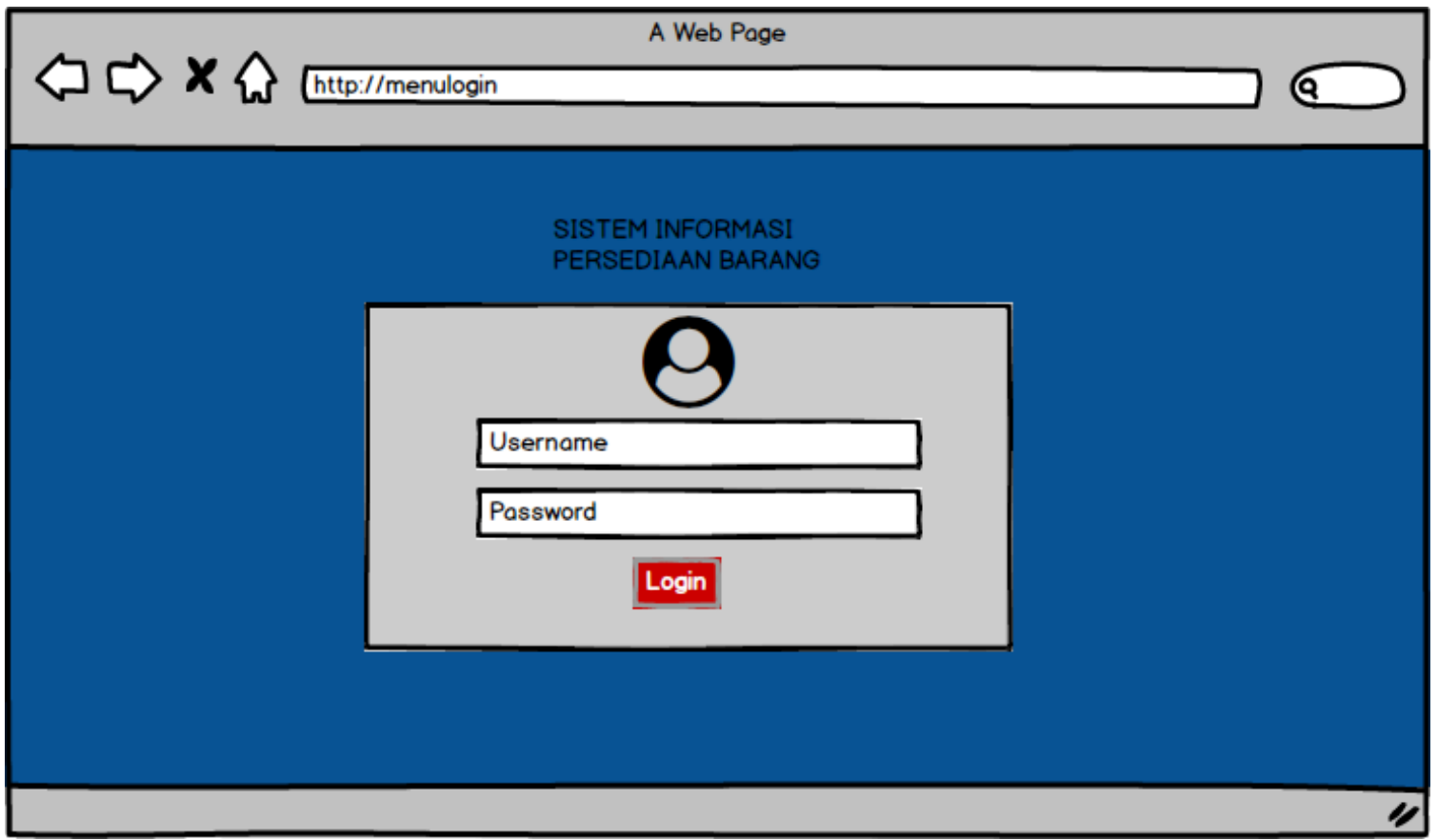

Figure 3. Display of Login Page

The above layout will appear if the user has entered the web browser and wants to log in to the system. Users must enter their username and password and choose LOGIN to access if they want to enter the system. Those who can access this program are warehouse admin, sales department, and leader who already has a username and password. The layout above is the username and password for the warehouse admin.

\section{B. Display of the Home Page}

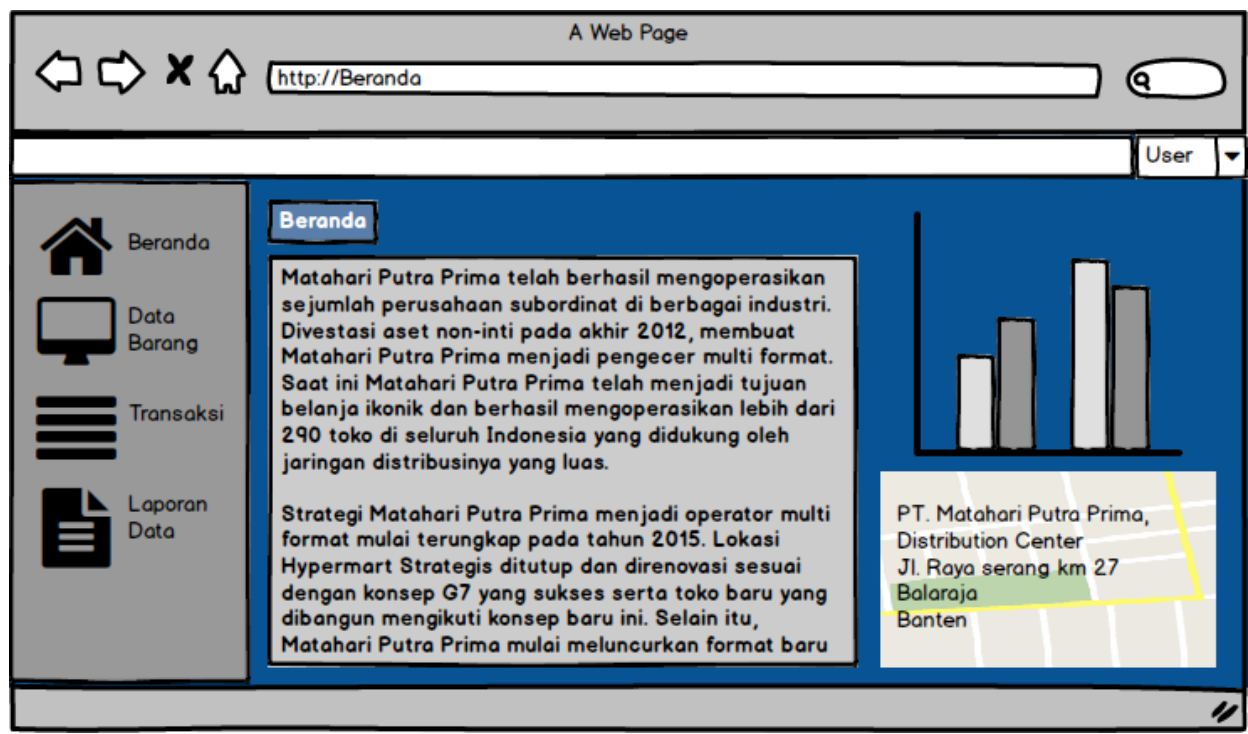

Figure 4. Display of the Home Page 
Layout This Dashboard page is the initial part that appears after logging in. This Dashboard display will appear when the user has successfully logged in. Which contains company history, statistics and company addresses.

\section{Tampilan Halaman Data Barang}

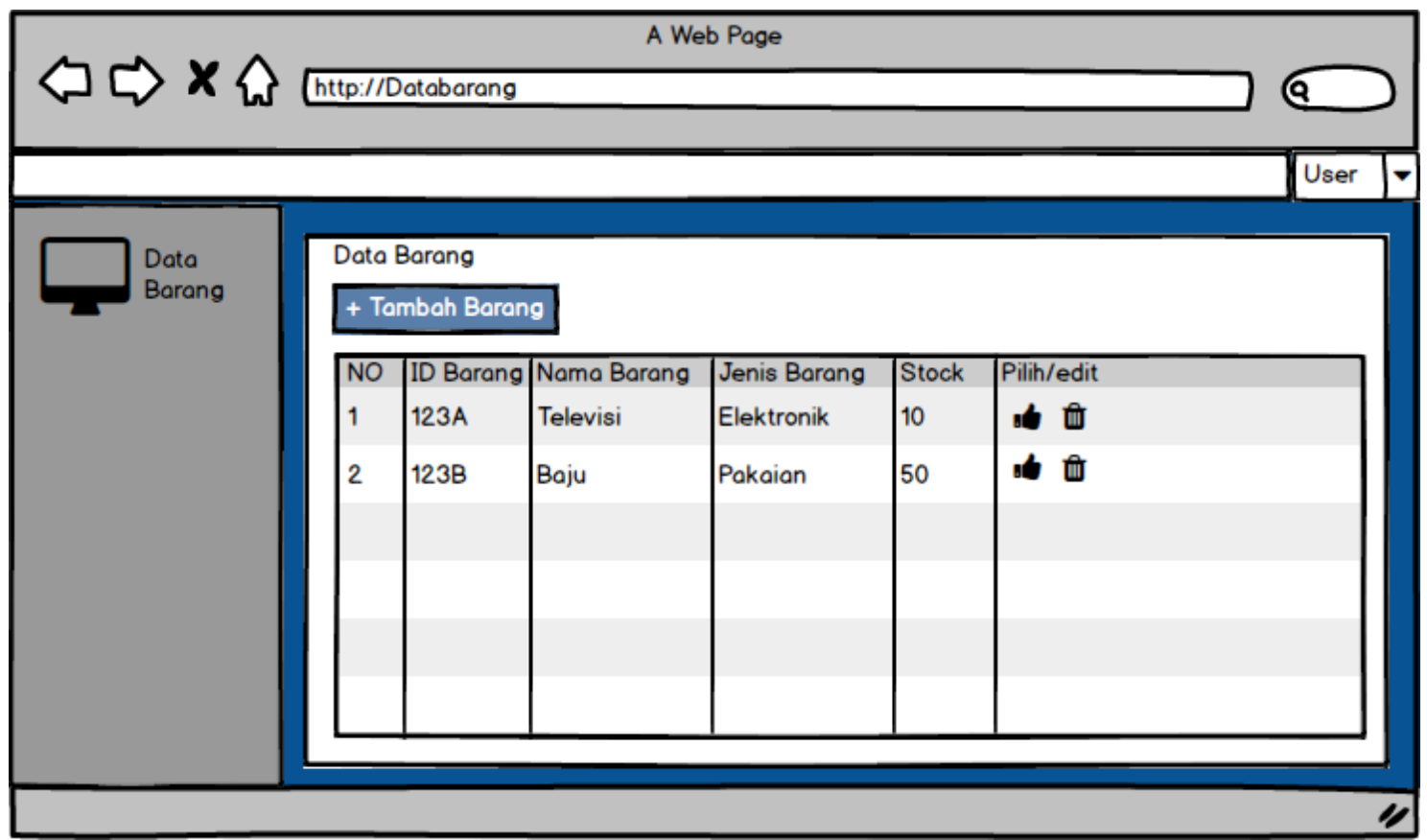

Figure 5. Display of Goods Data Page

This Data Item Layout is to add data on incoming or outgoing items and can be deleted or edited or deleted by the admin section.

D. Display of Transaction Page (Entry Item)

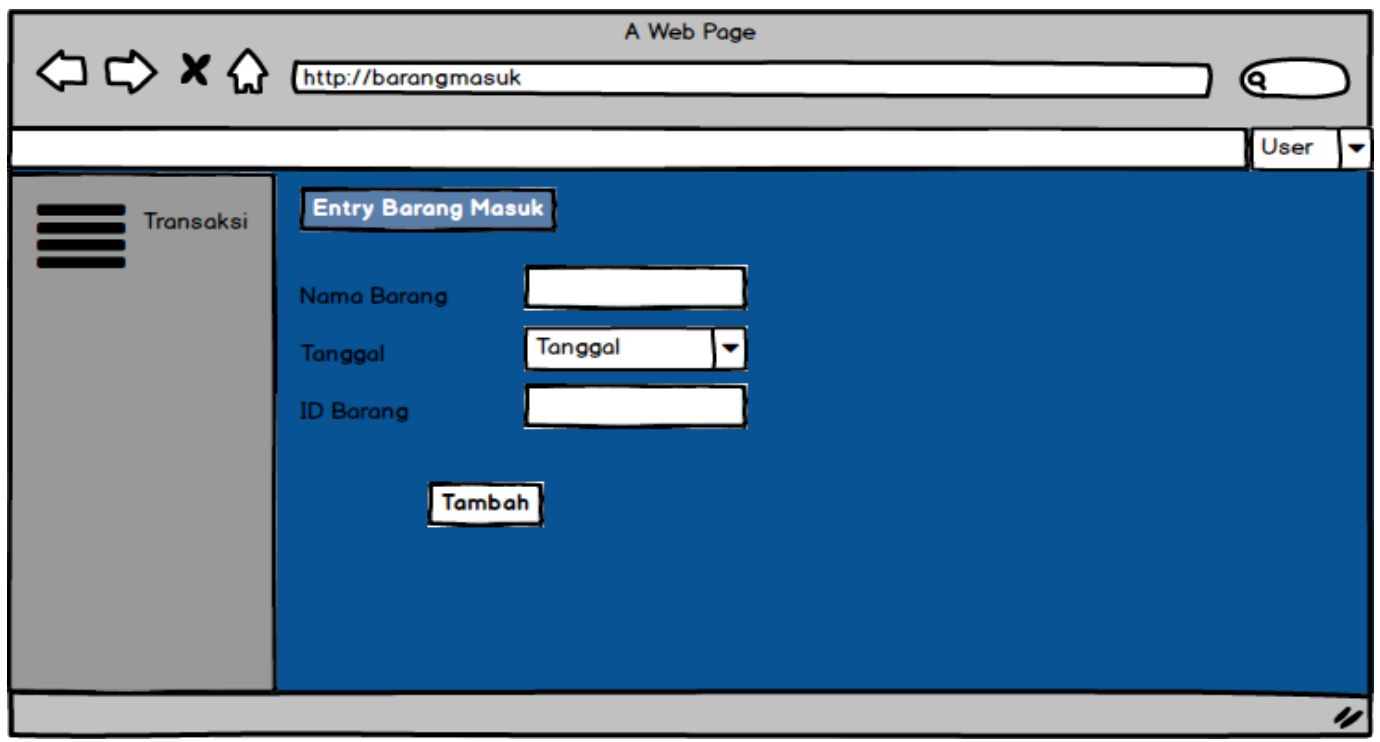


Figure 6. Display of Transaction Page (Item entered)

In the layout of the incoming goods transaction page it is for entry of goods that contain the goods name, date and item ID.

\section{E. Tampilan Halaman Transaksi (Barang Keluar)}
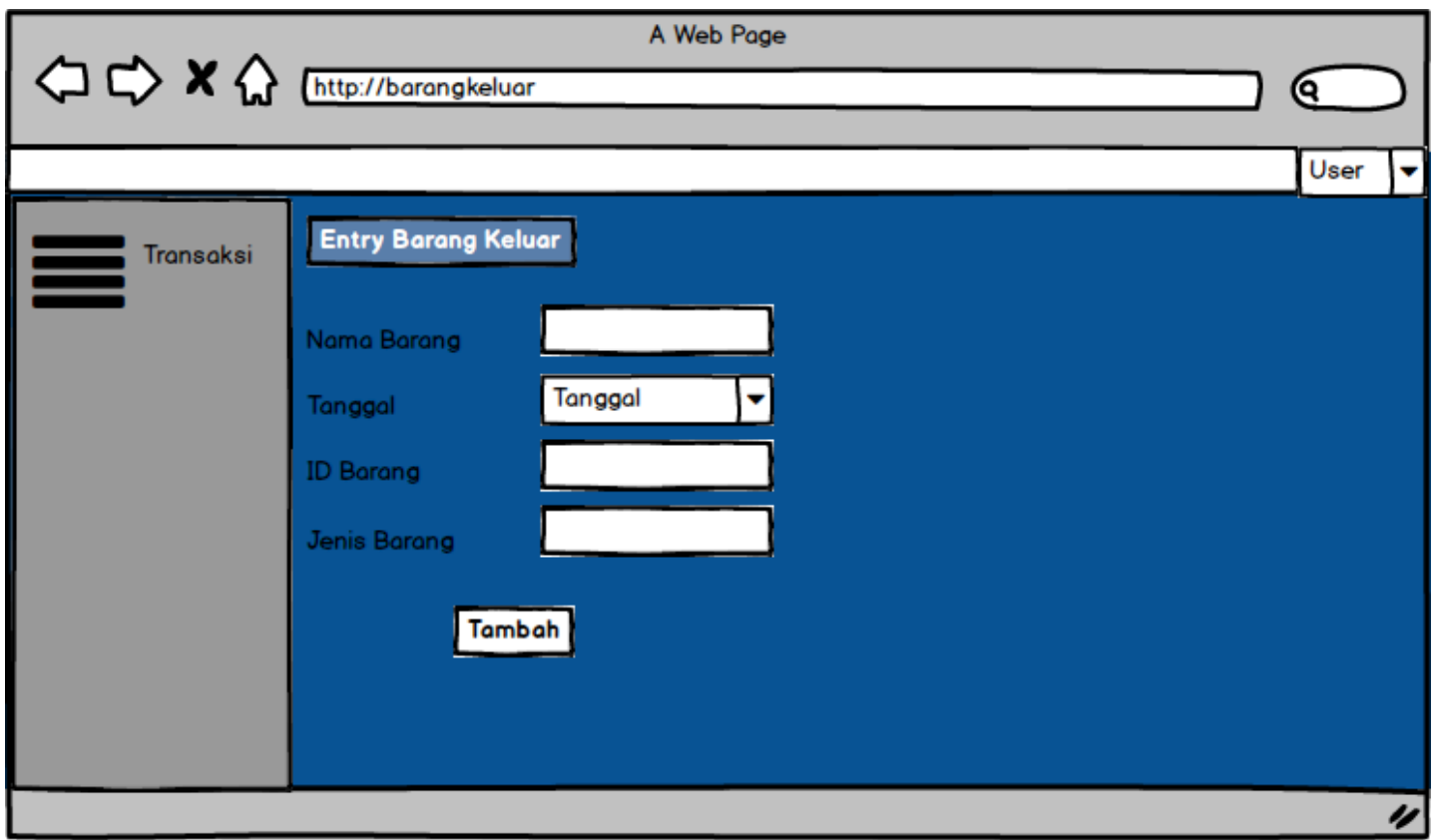

Figure 7. Display of Transaction Page (Exit Item)

\section{F. Report Page Display}

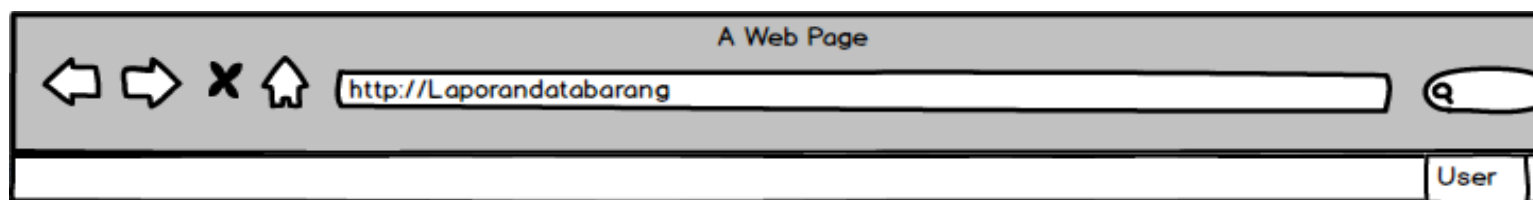

Laporan Dato

Barang

Cetak

\begin{tabular}{|c|c|c|c|c|c|c|}
\hline NO & ID Barang & Nama Barang & Jenis Barang & Stock & Edit & Hopus \\
\hline 1 & $123 \mathrm{~A}$ & Televisi & Elektronik & 10 & & \\
\hline 2 & $123 B$ & Baju & Pakaian & 50 & Edit & Hopus \\
\hline
\end{tabular}

Figure 8. Report Page Display 
This Report Page Layout is report data consisting of item id, item name, type of item and stock. Which will later be printed to give a report to the leadership.

\section{Conclusion}

Based on the results of research conducted at PT. Matahari Putra Prima Tbk, it can be concluded that the inventory data information system of goods that is running at PT. Matahari Putra Prima Tbk is currently not optimal because it has not been able to manage data effectively and efficiently, so to be able to present the required inventory report requires a long time and the results are less accurate. Constraints and problems in information systems that are running are processes that are not efficient because they still use paper, procedures that are long and timeconsuming, as well as accuracy and speed in making reports are still less effective, because data processing still uses Micorsoft Excel so that calculation errors often occur and often once a data collection occurs. The process of monitoring inventory items at PT. Matahari Putra Prima Tbk, in ordering goods in large quantities the inventory of goods in the warehouse does not match the stock of goods ordered by Cutomer. Then it requires a system that can facilitate monitoring of data collection of incoming and outgoing goods in the inventory.

\section{References}

[1] Rahardja, U., et al. Utilization of Mailchimp as a Trend of Distribution of Payment Information for Students in Higher Education. Technomedia Journal (TMJ) Vol.2 No.2 Edition February 2018 E-ISSN: 2528 - 6544P - ISSN: 2620 -3383.

[2] Azizah, Nur et al. "The Design of SPG Employee Performance Evaluation Information System System Status in Softe Indonesia Using Simple Additive Weighting (SAW) Method". Tangerang: STMIK Raharja. Journal of SENSI. (Vol. 3 No. 2 August 2017 ISSN 2461-1409)

[3] Parrangan, Ezra Randalinggi, Srikandi Kumadji, Edy Yulianto. 2015. "Analysis of the Company's Strategy in Expansion of Foreign Markets (Case Study at PT Semen Indonesia (Persero) Tbk in the Acquisition of Thank Long Cement Company in Vietnam). Malang: Brawijaya University. Business Administration Journal. Vol. 26 No. 2.

[4] Ciarmiello, Andrea, Luciano Hinna. 2016. "Italy SWOT Analysis and Stakeholder Engagement for Comparative Evaluation of Hybrid Molecular Imaging Modalities". International Journal of Springer International Publishing Switzerland, Department of Nuclear Medicine, Second University of Naples, Department of Nuclear Medicine. Department of Nuclear Medicine, S. Andrea Hospital, La Spezia, Italy, Volume, 271282, ISSN: 978-3-319-31612-3.

[5] Susena, Edy. Ema Utami, Andi Sunyoto. 2015. "Strategic Planning for Smart Campus Information Systems to Improve Services at Indonusa Surakarta Polytechnic". Sainstech Journal Polytechnic Indonusa Surakarta: Vol. 1, Number 3 ISSN: 23555009

[6] Masykur, Fauzan. 2014. "Implementation of Geographic Information System Using Google Maps Fire in Student Origin Mapping". Ponorogo: Muhammadiyah University Ponorogo. SIMETRIS Journal, (Vol. 5 No. 2 November 2014 ISSN: 2252-4983

[7] Aris, A., Firdaus, T., \& Nurseha, N. (2018). APPLICATION OF GOODS QUALITY CONTROL PROGRAMS TO SUPPORT REPORTING IN THE RAHARJA HIGHER EDUCATION TECHNIQUES PART. STORY Journal, 4 (2), 159-168

[8] Maulani, G., Septiani, D., \& Sahara, P. N. (2018). DESIGN OF INVENTORY INFORMATION SYSTEM FOR MAINTENANCE FACILITIES IN. PLN (PERSERO) TANGERANG. ICIT Journal, 4 (2), $156-167$ 
[9] Ahmad Budiman, Asri Mulyani (2016) DESIGN AND DEVELOPMENT OF APPLICATION INFORMATION SYSTEMS FOR GOODS IN TB. INDAH JAYA BASED ON DESKTOP Journal of Algorithm of the College of Technology in Garut Vol 13, No. 1

[10] Supriyanti, Dedeh, Yudo Bangun Romadhon, Dedy Iskandar. 2015. Information System for Inventory of Goods at Pt. Hankook Ceramic Indonesia. STORY Journal. Tangerang: STMIK Raharja. ISSN: 2461-1417 Vol.1 No.1 - August 2015.

[11] Astriyani, Erna, Rahmadi, Ahmad Ricky Alfariz. 2017. Design of Stock Stock Procurement System at Pt. Jaya Grace Rate. STORY Journal. Tangerang: STMIK Raharja. ISSN: 2461-1417 Vol 3 No 1 - February 2017

[12] Samsuni, S. (2017). Manajemen sumber daya manusia. Al-Falah: Jurnal Ilmiah Keislaman dan Kemasyarakatan, 17(1), 113-124. 